\title{
Performance of Health Facilities in Relation to Capitation Payments
}

\author{
Meridian Geodesi ${ }^{1}$ and Ratna Wardani,** \\ ${ }^{1}$ Ploso Regional General Hospital, Jombang, East Java, Indonesia \\ ${ }^{2}$ Health management and service policy, Master of Health, Strada Institute of Health Sciences, \\ Indonesia
}

\section{ORCID}

Ratna Wardani: https://orcid.org/0000-0001-9508-1066

Corresponding Author: Ratna Wardan; email:

asmarawan.ratna08@gmail.com

Published: 7 February 2022

Publishing services provided by Knowledge E

(c) Meridian Geodesi and Ratna Wardani . This article is

distributed under the terms of the Creative Commons

Attribution License, which permits unrestricted use and redistribution provided that the original author and source are credited.

Selection and Peer-review under the responsibility of the IVCN Conference Committee.
G OPEN ACCESS
Abstract. Health facilities, in collaboration with BPJS Kesehatan, must organize health care efforts that are promotive, preventative, curative and rehabilitative. BPJS Kesehatan must collaborate with health facilities to implement a service quality control system and payment system for the efficiency and effectiveness of health insurance. The purpose of this research was to evaluate the performance of Puskesmas services in Jombang Regency, and to evaluate patient contact numbers, the ratio of non-specialist outpatient referrals and the ratio of Prolanis participants at health center services in Jombang Regency. This was qualitative research with a case study design. There were nine informants, including the Head of BLUD Puskesmas. Puskesmas contact numbers in Jombang Regency did not reach the target (150 permil). The outpatient referral ratio of non-specialist cases reached the target (less than $1 \%$ ). The ratio of regular Prolanis participants visiting FKTP reached the target ( $\geq 50 \%$ ), but in January-March 2021 this ratio decreased. The home visit ratio has not been implemented due to inadequate means of transportation. This research can be used as a reference to find ways to improve the components of KBKP so that it can maximize capitation payments.

Keywords: BPJS Kesehatan, FKTP, capitation based on service commitment, community health center

\section{Introduction}

Service quality control system and payment system to FKTP (Puskesmas) using Capitation Based on Fulfillment of Service Commitments based on the Joint Regulation of the Secretary General of the Ministry of the Republic of Indonesia and the President Director of BPJS Health Number HK.01.08/II/980/2017 Number 2 of 2017 concerning Technical Guidelines Implementation of Capitation Payments Based on FKTP Service Commitment Fulfillment which is an adjustment to the capitation rate as seen from the achievement of FKTP service commitment (Puskesmas) fulfillment indicators in order to improve the quality of health services. The service commitment indicators in question include a Contact Rate 150 per mile, a Non-Specialist Referral Ratio <5\% and a Prolanis Participant Ratio for Routine Visits to FKTP 50\% [1]. 
The difference in the number of capitations received by FKTPs is not only caused by differences in the number of participants registered in the FKTP, but also because of the results of credentialing and recredentialing carried out by BPJS Kesehatan. FKTP consists of Puskesmas, doctor's practice, dentist practice, Primary Clinic, Primary Class D Hospital, and all equivalent health facilities. Capitation based on fulfillment of service commitments is an adjustment to the amount of capitation rates based on the results of an assessment of the achievement of individual health service indicators that are mutually agreed upon [1] in Jombang Regency, the achievement of the KBPKP indicator targets in FKTP, especially Level I Health Facilities, can be said to be not optimal because in July s.d. September 2020, from 34 Level I Health Facilities, 10 Level I Health Facilities met the three indicators and received a 100\% capitation payment, 11 Tier I Health Facilities that met two indicators and received a 95\% capitation payment, and 13 Tier I Health Facilities. Who can meet one indicator and get a capitation payment of 92.5\% [2]. The following is data on the achievement of the KBK Indicator from October to November 2020 for several Puskesmas.

The achievement of the KBK indicators for the Jombang Health Center was categorized as follows in accordance with the achievement of targets:

1. Category A (100\% achievement) Bawangan Health Center, Jelakombo Health Center, Pulo Lor Health Center, Blimbing Gudo Health Center, Jatiwates Health Center, Megaluh Health Center, Tapen Health Center, Keboan Health Center, Peterongan Health Center, Dukuh Klopo Health Center, Jarak Kulon Health Center, Sumobito Health Center, Kesamben Ngoro Health Center, Mojowarno Health Center, Bareng Health Center and Wonosalam Health Center

2. Category B ( 95\% Achievement) Kesamben Health Center, Japanan Health Center, Mayangan Health Center, Mojoagung Health Center, Plandaan Health Center, Kabuh Health Center, Tembelang Health Center, Bandar Kedungmulyo Health Center, Brambang Health Center, Tambak Rejo Health Center and Cukir Health Center

3. Category C ( $90 \%$ Achievement) Jabon Health Center, Plumbon Gambang Health Center, Perak Health Center, Gambiran Health Center, Jogoloyo Health Center, Blimbing Kesamben Health Center and Pulorejo Ngoro Health Center.

This KBPKP indicator has not been achieved yet because the understanding of the implementation of Capitation Based on Fulfillment of Service Commitments in the field is not optimal because most of them have different understandings [3]. The KBPKP policy still requires socialization and technical guidance from the Health Office and 
BPJS Health to all Level I Health Facility officers [4] so it is necessary to optimize the function of coordination and socialization related to the implementation of KBPKP which requires communication.[5] explains that communication will determine the success of achieving the objectives of a policy implementation, including the implementation of the KBPKP policy. The implementation of the KBPKP that has not been optimal is also due to the limitations of existing human resources or supporting infrastructure [4]. The results of the study [4] state that the achievement of the KBPKP indicator target at the puskesmas is influenced by the availability of human resources, infrastructure, and methods of implementing activities that are integrated with program activities at Level I Health Facilities. Level I Health Facilities as one of the providers of health services at the first level are expected to be able to become gatekeepers by prioritizing health efforts that are promotive and preventive. However, in practice, curative and rehabilitative services dominate, while the scope of health services in the JKN era explains that the services provided must be comprehensive, including strengthening promotive and preventive efforts [1]. Based on the explanation above, the researcher is interested in examining the performance evaluation of Level 1 Health Facilities on BPJS capitation payments in Jombang Regency. The general purpose of this study was to evaluate the performance of Puskesmas services in Jombang Regency, while for specific purposes were to evaluate Patient Contact Rates at Puskesmas Services in Jombang Regency, to evaluate the Non-Specialist Outpatient Referral Ratio at Health Center Services in Jombang Regency, to evaluate the Prolanis Participant Ratio. on Health Center Services in Jombang Regency and the ratio of home visits.

\section{Methods and Equipment}

This research is a qualitative research with a case study research design, the data source is obtained from two data sources, the first is in-depth interviews with research informants, namely the community health center, and the second is data from documents, namely the profile of the community health center. data collection techniques with observation and interviews. The research process takes place from January to March 2021. In general, the results to be achieved in the research are regarding the implementation of the use of capitation funds at the Jombang District Health Center. Informants in this study amounted to nine people consisting of the Head of BLUD Puskesmas.

In this study, researchers will conduct in-depth interviews with informants consisting of the Head of the Puskesmas to explore the same topic and compare the answers 
from the informants to obtain compatibility and conclusions. Determination of informant criteria greatly helps researchers to eliminate the results of the study. Criteria in the selection of informants of this study include:

1. Inclusion criteria : 1) Head of Health Center in collaboration with BPJS, 2) Ready to be an informant

Exclusion Criteria : 1) Health centers that do not cooperate with BPJS, 2)Faskes Level 1 with 100\% coverage, 3) Head of BLUD Puskesmas who is not willing to be studied

The triangulator is Head of BLUD Puskesmas with $100 \%$ KBKP achievement amounted to 4 people.

\section{Result}

Service Commitment-Based Capitation System is a system of adjusting the amount of capitation rates based on the results of the assessment of the achievement of FKTP service commitment indicators in order to improve service quality. The implementation of the Service Commitment-Based Capitation system is assessed based on the achievement of indicators which include:

\section{Contact Number}

The contact number is one indicator of service commitment to determine the level of accessibility and utilization of primary services at the Jombang Health Center by JKN participants without taking into account the frequency of participant arrivals in one month, both inside and outside the puskesmas building.

\section{Target Achievement.}

The achievement of the contact number indicator target by FKTP consists of targets in the safe zone and achievement zone. Aim for a safe zone of at least 150 per mile each month and a target for an achievement zone of at least 250 per mile each month.The Jombang Health Center contact number indicator did not reach the target in the safe zone for three consecutive months, namely in January, February, and March 2021. The trend of achieving the contact number indicator below the safe zone was caused by the low utilization of participants in making contact with FKTP, both inside and outside the building. This is in accordance with the results of research by [6] which stated that the contact number of the Juwana Health Center was still far below the target indicator. The 
reason is the lack of implementation of the first contact function at the Juwana Health Center, due to the low utilization of registered participants to make communication contacts with the puskesmas. Registered participants still have the mindset that FKTL has better services so that FKTP is only used to request referral letters to FKTL.Health workers at the Jombang Health Center are also aware that achieving the target contact rate indicator is difficult because it has a fairly large target, which is 150 per mil. In terms of quantity, health workers at the Jombang Health Center have met the health center personnel standards in accordance with the Minister of Health Regulation No. 75 of 2014 concerning Puskesmas. However, the activities carried out are quite numerous, resulting in the doubling of tasks or concurrent positions

\section{Barriers to Achieving Targets}

Barriers to Achieving Targets An obstacle is something that weakens or hinders that comes from within. The obstacles experienced in achieving the target indicator of the Jombang Health Center contact number are limited human resources or health workers with quite a lot of activities or workloads. This is in line with the results of [4] that the achievement of the contact number indicator is influenced by the availability of human resources and methods or activity planning. The Jombang Health Center has challenges in achieving the contact number indicator target. The challenge is the public's perception of health services. People come to health services when they feel sick. In accordance with the results of research by [7] which states that participants have not made the puskesmas their first place to access health services, both in promotive and preventive approaches. The puskesmas should be interpreted as a gate keeper or the first contact in formal health services as well as strengthening promotive and preventive services. However, in reality until now the puskesmas is still a health service with a curative and rehabilitative approach [8] also suggests that the contact number indicator target has not been achieved due to a lack of knowledge of participants about services at FKTP which emphasizes promotive and preventive activities. Participants generally only visited FKTP if they wanted treatment. Therefore, FKTP needs to provide promotion and education to participants to come to FKTP in droves even though they are in good health.

\section{Outpatient Referral Ratio for Non-Specialized Cases}

The ratio of non-specialist outpatient referrals is an indicator to determine the quality of services at the Jombang Health Center so that the referral system is implemented according to medical indications and competencies. 


\section{Target Achievement}

The achievement of the target ratio indicator for outpatient referrals for non-specialist cases by FKTP consists of targets in the safe zone and achievement zone. The target in the safe zone is less than $5 \%$ every month and the target in the achievement zone is less than $1 \%$ every month.The ratio of outpatient referrals for non-specialist cases at the Jombang Health Center in January, February, and March 2021 has reached the target in the achievement zone. Since the Service Commitment-Based Capitation system was implemented at the Jombang Health Center, the number of referrals, especially referrals for non-specialist cases, has decreased. This is in line with the results of a review of the implementation of Service Commitment-Based Capitation by [9] which states that the national achievement of the non-specialist case referral ratio has reached the target in June of $1.40 \%$. If the non-specialist referral rate can be reduced to $0 \%$, then the goal of the Service Commitment-Based Capitation system can be achieved, namely increasing the quality of health services in FKTP.In meeting the target ratio indicator for outpatient referrals for non-specialist cases at the Jombang Health Center, doctors are required to be more selective and understand their competence in providing referrals. The same thing was also stated by [8] that the ratio of outpatient referrals for non-specialist cases was influenced by many factors, one of which was the ability of doctors. Since the Service Commitment-Based Capitation system was implemented, referrals have become more concerned. This is so that the puskesmas does not experience a decrease in capitation.In addition, the Jombang Health Center has a strategy or method in meeting the target ratio indicator for outpatient referrals for non-specialist cases. The Jombang Health Center has an agreement with BPJS Health, namely if there is a referral that is forced to be given by the puskesmas, then the referral is given a code or sign that has been agreed with BPJS Health. This method is proven to be able to reduce the ratio of outpatient referrals for non-specialist cases at the Jombang Health Center.

\section{Challenges in Achieving Target}

The ratio of outpatient referrals for non-specialist cases at the Jombang Health Center has reached the target in the achievement zone. Achieving the target in the achievement zone is inseparable from challenges. Achieving the target indicator ratio for outpatient referrals for non-specialist cases at the Jombang Health Center has challenges, such as patient understanding of the flow of referral services. The patient is forced to ask for a referral with a diagnosis of a disease that can still be handled by the FKTP, one of which is hypertension. This is in line with the results [8] which suggests that in the implementation of referrals, there are still diagnoses of referred diseases which are 
FKTP competencies and there are still patients who ask to be referred for reasons, especially suggestions of patients who trust the competence of specialist doctors. The results of [7] also state that referrals for non-specialist cases still occur due to the will of the patient. The Jombang Health Center is experiencing challenges where it faces the wishes of the community with policies that require it to act according to the rules.

\section{Ratio of Prolanis Participants Regularly Visiting FKTP}

The ratio of prolanist participants who regularly visit FKTP is an indicator to determine the condition or condition of chronic disease services which can be seen from the form of FKTP's contact with prolanist participants.

\section{Implementation of Prolanis}

The implementation of the puskesmas level is an effort to mobilize puskesmas employees in such a way that puskesmas employees have commitment and responsibility, support and work together, have the will and work ability, like work, become good employees, and strive to achieve puskesmas goals.The implementation of Prolanis using a proactive approach is carried out in an integrated manner in the context of health care for BPJS Health participants who suffer from chronic diseases to achieve an optimal quality of life. The form of implementation of prolanis is as follows:

1. Activities in the Implementation of Prolanis

According to Joint Regulation No. 3 of 2016 concerning Technical Instructions for Implementing Capitation Payments Based on Fulfillment of Service Commitments at FKTP, activities in the implementation of Prolanis include club education, medical consultations, health monitoring through supporting examinations, prolanis exercise, home visits, and routine drug services (DRR drugs).

The prolanis activities that have been carried out at the Jombang Health Center consist of five activities:

1. Club Education.

Club education in some health centers in Jombang has been implemented. Club education is held once a month with free participants, not only Prolanis participants.

1. Medical Consultation.

Medical consultations at the Jombang Health Center have been carried out but have not been optimal. In accordance with the BPJS Prolanis Practical Guidelines, medical 
consultations have an agreed schedule of consultations between prolanis participants and the FKTP. However, the results of the study indicate that medical consultations can be carried out every day without an agreed schedule between the prolanis participants and the FKTP.

1. Health monitoring through follow-up examination.

Health monitoring through supporting examinations is carried out once a month. The health check on prolanis consists of checking blood sugar, blood pressure, and weight.

1. Prolanis Gymnastics.

Some health centers do prolanis gymnastics once a week at their respective health centers.

1. Routine Drug Service (DRR Drug).

Drug service activities for prolanis participants are carried out after a health check. DRR drug services are carried out every Friday at the Jombang Health Center. The implementation of prolanis activities at the Jombang Health Center has not been carried out in accordance with the established regulations. Of the six designated activities, only five prolanis activities were carried out at the Jombang Health Center, including club education, medical consultations, health checks through supporting examinations, prolanis exercise, and routine drug services (PRB drugs). Activities that have not been carried out are home visits. The same thing was also stated by [7] with the results of research in Sukoharjo that the prolanis activities that had been carried out only consisted of four activities, such as health counseling, health checks, prolanis exercise, and drug administration. Activities that have not been carried out are medical consultations and home visits. This is because the management of activities at the puskesmas is different because there is no special SOP for prolanis.

\section{Target Achievement.}

The achievement of the target ratio indicator of prolanis participants regularly visiting FKTP consists of targets in the safe zone and achievement zone. The target in the safe zone is at least $50 \%$ every month and the target in the achievement zone is at least $90 \%$ every month.The ratio of prolanis participants who regularly visit the FKTP has reached the target in the safe zone. However, in the past few months, the ratio of prolanis participants who regularly visit FKTP has decreased. Nationally, the ratio of prolanist participants who regularly visit FKTP has also decreased, even below the safe zone 
target. From the results of a review of the nimplementation of Service CommitmentBased Capitation by [8], the ratio of prolanist participants who regularly visit FKTP in May is $33.77 \%$ and June is $25.90 \%$. This is because not all FKTPs that implement KBK have prolanist clubs. [7] also states that Prolanis at the Juwana Health Center has not been implemented. Of the 29 health centers in Pati Regency, only four health centers have formed a prolanis club with prolanis gymnastics and club education activities. The decrease in the achievement of the indicator of the ratio of prolanis participants to routine visits to FKTP was caused by no agreement on a schedule to conduct medical consultations between prolanis participants and prolanis implementers at the Jombang Health Center. Based on the $\mathrm{i}$, medical consultation activities must have a mutually agreed consultation schedule between Prolanis participants and FKTP. With the agreed consultation schedule, Prolanis participants regularly receive chronic disease services. In addition, the indicator of the ratio of prolanis participants who regularly visit the FKTP can also reach the safe zone to the achievement zone.

\section{Barriers to Achieving Targets.}

The obstacle experienced in achieving the target ratio indicator of prolanist participants regularly visiting FKTP is the lack of human resources or prolanist personnel which causes doubling of tasks so that the prolanist staff is not only responsible for the prolanist. On the same day and time, prolanis staff must be responsible for other programs. This has an impact on prolanis activities that do not run optimally. In accordance with the results of research conducted by [10] which suggests that there is still a shortage of human resources for the implementation of prolanis. The impact of this lack of human resources causes the doubling of tasks for prolanis implementers. In addition, the work area is quite large and the lack of transportation facilities is an obstacle in carrying out prolanis activities. This has an impact on one of the prolanis activities that cannot be carried out, namely home visits. The obstacle in carrying out prolanis activities is when they invite the public to participate in prolanis activities which are carried out on working days and hours. Efforts made by the Jombang Health Center are conducting education and health checks in crowded places, such as in markets. However, this is not done routinely. The same thing was also stated by [11] that not all forms of prolanis activities can be carried out according to prolanis guidelines on the grounds that there is no place, busyness, and unwilling participants so that the implementation of prolanis is not optimal.

\section{Home Visit Ratio.}


The home visit ratio is a special additional indicator for puskesmas in fulfilling service commitments in the form of home visit activities with a family approach that aims to determine the implementation of promotive and preventive activities.

\section{Target Achievement.}

An additional indicator of service commitment is in the form of home visits with a family approach to achieve the Healthy Indonesia Program for all families in the working area of the puskesmas regardless of JKN participants or non-JKN participants. This activity is carried out to achieve a healthy family index which is seen based on 12 main indicators that indicate a family's health status.Based on the General Guidelines for the Healthy Indonesia Program with a Family Approach, home visits are carried out on a scheduled and routine basis by utilizing data and information from the Family Health Profile (family folder). In reaching families, puskesmas do not only rely on existing community-based health efforts (UKBM) as they have been implemented so far, but also have to visit families. It should be noted that this family approach through home visits does not mean turning off existing UKBMs, but strengthening UKBMs which have been felt to be ineffective. In addition, home visits are one of the strategies to achieve the target number of contact indicators.By visiting the family at their home, the puskesmas will be able to identify the health problems facing the family more thoroughly. Individual family members who need to receive health services can then be motivated to take advantage of puskesmas services. Families can also be motivated to improve environmental health conditions and various other risk factors that have been detrimental to their health. Therefore, 12 indicators for markers of family health status can be achieved and public health status will increase. The achievement of home visit activity indicators with a family approach is when the home visit ratio reaches $100 / 12 \%$ or about $8.33 \%$ per month. Thus, within one year RKR must be achieved $100 \%$ in order to get compensation in the form of training/workshops/seminars to improve the competence or performance of the puskesmas.

\section{Discussion}

It is difficult to achieve the target for the contact number indicator because the target is too large and collides with the number of personnel who have multiple tasks. The challenge for community health centers is how to change public perceptions of health services as access to promotive and preventive services, not curative and rehabilitative services. In achieving the indicator ratio for outpatient referrals, non-specialist cases 
have reached the target in the achievement zone, but how can doctors be more selective and understand their competence in providing referrals to hospitals. In the indicator, the ratio of prolanis participants has decreased in several months due to the absence of an agreed schedule and lack of manpower. And lastly, the home visit ratio has not been maximized due to the large working area of the community health center compared to the lack of transportation and human resources.

The indicator of the contact number of the Jombang Public Health Center did not reach the target in the safe zone for 3 consecutive months, namely January, February, March 2021, this led to a reduction in the capitation payment received by the Jombang Health Center in accordance with the regulation that if the FKTP could not meet the set target, BPJS Kesehatan provides sanctions in the form of reducing capitation

The ratio of outpatient referrals for non-specialist cases at the Jombang Public Health Center in January, February and March 2021 has reached the target in the achievement zone. Especially since the service commitment-based capitation system has been implemented, giving more attention to referrals so that puskesmas do not experience a decrease in capitation, the puskesmas have agreed with BPJS health to provide an agreed code to reduce the ratio of outpatient referrals for non-specialist cases.

The achievement of the indicator target ratio of prolisic participants who regularly visit FKTP has reached the target in the safe zone, but within a few months the ratio of prolis participants who visit FKTP has decreased due to no agreed schedule for medical consultations. Based on the practical guidance of [1]. Medical consultation activities must have a mutually agreed consultation schedule

An additional indicator of service commitment in the form of home visit activities with a family approach regardless of JKN participants or non-JKN participants, but at the puskesmas home visit activities have not been carried out due to limited personnel at the puskesmas.

\section{Conclusion}

Based on the results of research and discussion that refers to the purpose of the study, it can be concluded as follows:

1. Puskesmas Contact Numbers in Jombang Regency as large as possible did not reach the target in the safe zone of 150 permil. This is due to the limitations of 
human resources and the perception of health centers that are only a place of treatment or curative services.

2. Outpatient Referral Ratio of Non-Specialist Cases of Puskesmas in Jombang Regency reached the target in the achievement zone (less than 1\%). This is due to the provision of codes on referrals given by the puskesmas.

3. Ratio of Regular Prolanis Participants Visiting FKTP reached the target in the safe zone ( $\geq 50 \%$ ), but in January February and March 2021 decreased. This is due to the lack of human resources in carrying out Prolanis activities, a large enough puskesmas working area, and inadequate transportation facilities. Prolanis activities are carried out at the Health Center in Jombang Regency there are 5 out of 6 activities that are determined, including club education, medical consultations, health monitoring through supporting examinations, Prolanis gymnastics, and regular drug services (PRB drugs).

4. Home Visit Ratio has not been implemented puskesmas in Jombang Regency. This is due to inadequate means of transportation.

5. This research aims to contribute as a reference and understanding to find ways how to raise the components of KBKP so that it can increase capitation achievement to the maximum.

\section{Funding}

This work is funded privately by the author.

\section{Acknowledgement}

The authors would like to thank their colleague for their contribution and support to the research. They are also thankful to all the reviewers who gave their valuable inputs to the manuscript and helped in completing the paper.

\section{Conflict of Interest}

The authors have no conflict of interest to declare. 


\section{References}

[1] Badan Penyelenggara Jaminan Sosial. Badan penyelenggara jaminan sosial. 2015.

[2] Badan Penyelenggara Jaminan Sosial. Badan penyelenggara jaminan sosial. Jombang; 2020.

[3] Nursalam RS, Utami S. Asuhan keperawatan bayi dan anak (untuk perawat dan bidan). Jakarta: Salemba Medika.

[4] Meri L. Analisis faktor-faktor yang mempengaruhi pencapaian indikator kapitasi berbasis pemenuhan komitmen pelayanan pada puskesmas di kota padang tahun 2016.

[5] Putra RH, Khaidir A. Concept of George C. Edwards III on implementation of regional regulations No. 12 of 2017 concerning youth in granting youth service in West Sumatera. International Journal of Progressive Sciences and Technologies. 2019;15:236-242.

[6] Rahman AO, Ayu El. Pengaruh terapi antituberkulosis terhadap pertumbuhan penderita tuberkulosis anak di kota jambi. JAMBI MEDICAL JOURNAL" Jurnal Kedokteran dan Kesehatan. 2.

[7] Rahma A, Arso SP, Suparwati A. Implementasi fungsi pokok pelayanan primer puskesmas sebagai gatekeeper dalam program JKN (Studi di puskesmas juwana kabupaten pati). Jurnal Kesehatan Masyarakat. 2017;3:1-11.

[8] Suharsimi A. Prosedur penelitian suatu pendekatan praktek. $6^{\text {th }}$ ed. Jakarta: Rineka Cipta; 2006.

[9] Annisa F. Evaluasi penerapan kapitasi berbasis pemenuhan komitmen pelayanan dalam meningkatkan mutu pelayanan kesehatan di kota padang tahun 2019. 2019.

[10] Sitompul S, Suryawati C, Wigati PA. Analisis pelaksanaan program pengelolaan penyakit kronis (Prolanis) BPJS kesehatan pada dokter keluarga di kabupaten pekalongan tahun 2016. Jurnal Kesehatan Masyarakat. 2016;4:145-153.

[11] Rosdiana Al, Raharjo BB, Indarjo S. Implementasi program pengelolaan penyakit kronis (Prolanis). HIGEIA (Journal of Public Health Research and Development). 2017;1:140-150. 